\title{
The History Learning Activities and Outcomes in Inquiry and Expository Learning Model: Do Both Make a Difference?
}

\author{
Jumaisa \\ Institut Agama Islam Negeri Parepare \\ jumaisa@,iainparepare.ac.id
}

\begin{abstract}
This research examines student learning activities and outcomes in the inquiry and expository learning model at SMA Negeri 14 Makassar. The research used the experimental design. The sample of this research was all students at the Class X IIS of SMA Negeri 14 Makassar. It consisted of two groups: students of Class X IIS 2 as the experimental group and Class X IIS1 as the control group. The sample of this study was carried out using the Cluster Random Sampling technique. The data analysis technique used an independent sample t-test. The results found differences in the activities and learning outcomes of students' bistory taught using the inquiry and expository learning models. The activities and learning outcomes of the bistory of students tanght by the inquiry learning model are better than those taught by the expository learning model.
\end{abstract}

Keywords: Expository, Inquiry, Learning Activities, Learning Model, Learning Outcomes

\section{INTRODUCTION}

Teachers' job has been managed in a curriculum that works to maintain the objectives of learning history during implementation. The curriculum can be a barrier in implementing values such as multicultural values (Lestariningsih, Jayusman \& Purnomo, 2018). Learning objectives are closely related to the objectives of the history education curriculum. Then the learning objectives must refer to the achievement of basic in learning (Susanto, 2014). At the high school level, teaching history in schools aims to make students gain the ability to understand history. Teachers should change their method to increase the quality of students (Sayono, 2015) and need historical thinking (Ma'mur, 2008). They should innovate in teaching history (Abdi, 2020; Suryani, 2013; Saiman, 2011). Through history learning, the character of nations can be increased (Sirnayatin, 2017). Handy (2021) states that History learning can build historical awareness. Students can develop their competencies to explain chronologically and have knowledge about the past that can be used to understand and explain the process of development and change in society and socio-cultural diversity to find and grow national identity amid the life of the world community.

The purpose of learning history is to instill the spirit of love for the homeland, know the process of forming the Indonesian state, and increase students' sense of unity and integrity. It is also to know the process of Indonesian human civilization in particular and the world community in general from the past to the present (Agung, 2012). Learning history in schools has been less attractive to students. Many students consider lessons boring because they tend to memorize. Some even think that history lessons do not benefit because the study is a pastime (Aman, 2011). In addition to these reasons, many students ignore this history lesson not included in the National Examination, so they only consider history lessons as complimentary lessons. 
The attitude of students who tend to be apathetic towards history lessons is caused by many factors, both internal and external. External factors, for example, are related to the presentation of History subject matter which tends to be a series of boring facts, learning methods that are not following the subject matter of history, the lack of supportive learning facilities, and this has an impact on the less conducive history learning process. The internal factors include students' attitudes towards learnings that tend to be less optimistic and activities and results that tend to be below. Similar conditions are still found in SMA Negeri 14 Makassar, wherein students pay attention to the implementation of history learning and are not active in the learning process.

Based on direct observation of the lecture method's learning process, many students are less enthusiastic about implementing learning activities. This problem is because, of the 44 students in the combined Class IIS1, only 15 were active in the learning process, while the other students did not look too active in learning and playing, only playing and playing with their classmates. Based on the results of initial observations, the percentage of completeness in both classes was obtained, namely, in Class IIS1, 21 students completed, and 23 students who did not complete with a completeness percentage of $47.72 \%$, while in Class IIS2, 19 students completed, and 25 students who did not complete with a completion percentage of $43.18 \%$. Understanding these phenomena that the history learning process is not easy, while the other students did not look too active in learning and playing, just playing and playing with their classmates. Based on the results of initial observations, the percentage of completeness in both classes was obtained, namely, in Class IIS1, 21 students completed, and 23 students who did not complete with a completeness percentage of $47.72 \%$, while in Class IIS2, 19 students completed, and 25 students who did not complete with a completion percentage of $43.18 \%$. Thus, the history learning process is not easy and makes dull. Learning activities include physical and mental sides. In learning activities, these two activities must always be related. Student learning activities can be created by carrying out fun learning by presenting various learning models that further lead student activities. Thus, students will be more active during the learning.

This research chooses a learning model that focuses on developing students' abilities to find solutions to the problems they face. One of these learning models is the inquiry learning model. The inquiry learning model is a way of delivering lessons that develop scientific thinking (Anam, 2015; Putro, 2012) where students assimilate a concept or principle, for example, observing, classifying, making assumptions, explaining, measuring, and based on the experiences of students in everyday life. The inquiry method involves maximally the ability of students to search and search systematically, critically, logistically, analytically so that they can formulate their findings with confidence. However, there are still weaknesses in this learning model, such as requiring special abilities from the teacher.

In the teaching and learning process, teachers as facilitators, mediators, motivators, and evaluators. By looking at the advantages and disadvantages of the inquiry model, the type of inquiry model is required in SMA Negeri 14 Makassar. It is a guided inquiry that aims to train students (Kuswana, 2014) to have intellectual abilities (skills) to solve various problems that exist in their lives. The skill in question is that students can understand situations and events more quickly and get ideas to respond to these situations. In the guided inquiry learning model, students are placed as learning subjects to play an active role during the learning process, for example, in its application, involving all students' abilities to find phenomena critically and logistically. The purpose of this study was to determine the differences in the history learning activities of SMA Negeri 14 Makassar students between those taught with the Inquiry Learning Model and the Expository Learning 
Model and to determine the differences in the history learning outcomes of students at SMA Negeri 14 Makassar between those taught with the Inquiry Model and the Expository Learning Model. . The contribution in this research is to enhance the body of knowledge in the context of the learning process by developing an inquiry learning model as one of the references applied in a history learning process. In addition, this research can also be used as a reference for further research.

\section{METHOD}

\section{Research Design and Data Collection Techniques}

This research used the experimental method part of the quantitative method presenting a control group (Sugiyono, 2016). Experimental research uses a factorial design model, which is a modification of the true-experimental design. It pays attention to the possibility of moderating variables that affect the treatment (independent variable) on the results (dependent variable). In this design, all groups were selected randomly. Then each group was given a pretest. The research design model is presented in Table 1.

Table 1. Research Design

\begin{tabular}{|c|c|c|c|}
\hline \multicolumn{4}{|c|}{ Learning model } \\
\hline \multicolumn{2}{|r|}{ Inquiry (A1) } & \multicolumn{2}{|c|}{ Expository (A2) } \\
\hline \multicolumn{2}{|r|}{$\mathrm{Y}=(\mathrm{Y} 1, \mathrm{Y} 2)$} & \multicolumn{2}{|c|}{$\mathrm{Y}=(\mathrm{Y} 1, \mathrm{Y} 2)$} \\
\hline Y1.1 & Y1.2 & Y2.1 & Y2.2 \\
\hline (Experiment) & (Control) & (Experiment) & (Control) \\
\hline \multicolumn{4}{|l|}{ Information: } \\
\hline $\mathrm{Y}=(\mathrm{Y} 1, \mathrm{Y} 2)$ & $=$ Vector mean value & & \\
\hline Y1 & $=$ History Learning Activities & & \\
\hline Y2 & $=$ History Study Results & & \\
\hline A1 & = Inquiry Learning Model & & \\
\hline A 2 & $=$ Expository Learning Model & & \\
\hline
\end{tabular}

The data collection technique used in this study was the provision of tests to obtain data on learning outcomes. The test used to measure learning outcomes were multiple-choice questions with 20 items used in the posttest. The posttest was conducted after the experimental group was given an inquiry learning model, and the treatment class was given an expository learning model.

\section{Population and Sample}

The population of this study is all students of SMA Negeri 14 Makassar, which are spread over three levels, with the total number of classes being 26 (Table 2). Based on randomization, this research obtained Class $\mathrm{X}$ as a place of experimentation with the treatment of the inquiry and expository learning models. Furthermore, Class X consists of two majors, namely X MIA and X IIS. Those who received the treatment of the inquiry learning model and the expository learning model were Class X IIS through randomization as the experimental group. Thus, two classes were obtained as a place for researching to find out that the two selected classes were the same in terms of the initial ability of learning outcomes.

Table 2. Population of SMA Negeri 14 Makassar

\begin{tabular}{cccc}
\hline No & Grade & Number of Classes & Number of Students \\
\hline 1. & $\mathrm{X}$ & 8 & 269 \\
\hline 2. & $\mathrm{XI}$ & 9 & 295 \\
\hline
\end{tabular}




\begin{tabular}{cccc}
\hline 3. & XII & 9 & 292 \\
\hline & Total Population & 26 & 856 \\
\hline
\end{tabular}

The sampling technique in this study was carried out using the Cluster Random Sampling technique. It is a technique for selecting a sample of a small group of units. The population of the cluster is a subpopulation of the total population. Cluster grouping generates heterogeneous element units. After that, Class X IIS was taken as an experimental group, and Class X IIS1 was used as a control group.

Table 3. Research Population of Class X IIS Students of SMA Negeri 14 Makssar

\begin{tabular}{ccc}
\hline No & Class & Number of Students \\
\hline 1. & X IIS 1 & 32 \\
\hline 2. & X IIS 2 & 24 \\
\hline & Total Students & 56 \\
\hline
\end{tabular}

\section{Research Variables and Data Analysis Techniques}

There were two variables in this study, namely the independent variable and the dependent variable. The independent variable in this study was the learning model, namely the inquiry learning and the expository learning models. At the same time, the dependent variables in the study are student history learning activities as the Y1 variable and student history learning outcomes as the Y2 variable.

The instruments in this study consisted of two, namely instruments related to the implementation of history learning. In this case, it is the history of specialization using the inquiry learning model in research design. The second instruments were participants' activities and learning outcomes in activity assessment questionnaires and test questions to see student learning outcomes. These guidelines were used in the initial and final tests, both in the experimental and control groups.

Learning is carried out for five meetings. The first meeting was a preliminary test, and the second, third, and fourth meetings were treated, and at the fifth meeting, it was given a posttest. This treatment is different between the control and experimental groups. The control group used an expository model for its treatment, while the experimental group used an inquiry learning model as a form of treatment for students. Each meeting was conducted in $3 \times 45$ minutes.

The procedure for giving pretest and posttest is carried out with the following steps. Firstly, conduct pretest in both classes, including the experimental group and control group. The pretest results are used as a primary benchmark in the readiness of the sample in the research process. Second, the implementation of teaching and learning activities in both classes was given different treatment. The experimental group was treated with the inquiry learning model, and the control group was given an expository. Lastly, doing a final test (posttest) in both classes (the experimental and control groups). The posttest results are used as a standard for assessing the final learning outcomes.

In this study, there are two data including namely activity data and students' learning outcomes. Data obtained from student activity questionnaires would be analyzed and described to develop learning activities during the implementation of the inquiry learning model. The analysis technique used to test the research variables was an independent sample t-test. 


\section{RESULTS}

\section{Description of Learning Activities}

The learning process is carried out by accumulating the student learning activities based on the observation sheet. The following is the percentage of activity in the experimental group that applies the inquiry learning model.

Table 4. Statistics of Learning Activities in the Inquiry Learning Model

\begin{tabular}{cccc}
\hline Percentage of Student Activity & Criteria & Frequency & Percentage \\
\hline $76-100$ & High & 5 & 15.62 \\
\hline $51-75$ & Medium & 25 & 78.12 \\
\hline $26-50$ & Low & 2 & 6.25 \\
\hline $0-25$ & Very low & - & - \\
\hline & Amount & & 32 \\
\hline
\end{tabular}

For the expository model, it is shown as follows. It can be seen the number of students who have inquiry learning activities from 32 students, five students get the high criteria with a proportion of $15.62 \%$, and 25 students meet the medium criteria with a proportion of $78.12 \%$, and two students who get the low criteria with a percentage of $6.25 \%$. By looking at the activity intervals above, it can be said that, in general, the learning activities in the control group are in the medium category with a percentage of $78.12 \%$. Thus, by looking at the distribution of the proportion of students' learning activities, it can be said that the learning activities taught by the Inquiry learning model are higher than those taught by the expository learning model.

Table 5. Statistics of Learning Activities in the Expository Learning Model

\begin{tabular}{|c|c|c|c|}
\hline Percentage of Student Activity & Criteria & Frequency & Percentage \\
\hline $76-100$ & High & 19 & 79.16 \\
\hline $51-75$ & Medium & 5 & 20.28 \\
\hline $26-50$ & Low & - & - \\
\hline $0-25$ & Very low & - & - \\
\hline Amount & & 24 & 100 \\
\hline
\end{tabular}

There were no students who had to learn activities to implement the expository learning model of the 24 total students. Nineteen students get high criteria with $79.16 \%$, and five students meet medium criteria with a proportion of $20.84 \%$. By looking at the activity percentage intervals above, it can be said that, in general, the students' history learning activities in the experimental group are in the category with $79.16 \%$.

\section{Description of Student Learning Outcomes}

The data obtained is the pretest result before giving treatment to the inquiry learning model in the experimental group and the expository learning treatment to the control group. The statistical value of the experimental and control group is in Table 6.

Table 6. Summary of Statistical Values of Experimental group Pretest Results

\begin{tabular}{ccc}
\hline \multirow{2}{*}{ Parameter } & \multicolumn{3}{c}{ Value } \\
\cline { 2 - 3 } & Experiment & Control \\
\hline Number of Samples & 24 & 32 \\
\hline
\end{tabular}




\begin{tabular}{ccc}
\hline Mean & 26.04 & 35.31 \\
\hline Median & 25.00 & 32.50 \\
\hline Max & 45 & 60 \\
\hline Min & 15 & 10 \\
\hline Range & 30 & 50 \\
\hline Standard Deviation & 7.515 & 14,024 \\
\hline
\end{tabular}

Based on the results of the pretest data analysis of the experimental group, none of the students got a score of 100 as the maximum score. The highest score was 45 , obtained by one student, and three obtained the lowest 15 . On the other hand, none of the students scored 100 as the maximum score in the control group. Two students reach The highest score of 60 , and only one student gets the lowest score of 10 .

The data obtained is the result of the posttest after giving treatment to the inquiry learning model in the experimental group and the expository learning treatment to the control group. The statistical value of both group posttest results is in Table 7 .

Table 7. Summary of Experimental group Posttest Results Statistics

\begin{tabular}{ccc}
\hline \multirow{2}{*}{ Parameter } & \multicolumn{2}{c}{ Value } \\
\cline { 2 - 3 } & Experiment & Control \\
\hline Number of Samples & 24 & 32 \\
\hline Mean & 76.04 & 68.75 \\
\hline Median & 75.00 & 70.00 \\
\hline Max & 90 & 85 \\
\hline Min & 60 & 45 \\
\hline Range & 30 & 40 \\
\hline Standard Deviation & 9.205 & 9.837 \\
\hline
\end{tabular}

Table 8 shows that the final test was given to students in the experimental and control group. In the experimental group, none get a 100 score. The highest score was 90 , obtained by two students, and two obtained the lowest score of 60 . Nevertheless, in the control group, none get a 100 score. The highest score, 85 , was obtained by two students, and the lowest was 45 , obtained by one student.

\section{Model Fit Test}

The results of inferential statistical analysis are intended to answer the research hypothesis. However, before carrying out the inferential test, a prerequisite test for data analysis, commonly referred to as the assumption test, is carried out, namely the normality and homogeneity test. In the normality test, the data for the history learning activities of students in the inquiry learning model inferentially obtained the probability value $=0.102>=0.05$, and based on the normal curve, the score data for the history learning activity with the inquiry model follows the normal line. For students' history learning activities in expository learning inferentially the probability value $=0.60$ $>=0.05$ and follows the normal line. Meanwhile, the students' history learning outcomes in the Inquiry model learning, inferentially obtained the probability value $=0,057>=0.05$ and based on a normal curve, the data on students' history learning outcomes using the inquiry model follows the normal line. For students' history learning outcomes in expository learning inferentially, the probability value $=0.189>=0.05$ and follows the normal line. Thus, it can be said that the 
students' data on activity scores and learning outcomes came from a normally distributed population.

Based on the data homogeneity test for students' history learning activities in the Inquiry learning model, inferentially the probability value $=0.127>=0.05$ and for students' history learning activities in Expository learning inferentially the probability value $=0.129>=0.05$. This hypothesis (H1) is accepted, which means the data tend to be the same or homogeneous. While the students' history learning outcomes in the Inquiry model learning, inferentially obtained the probability value $=0.732>=0.05$ and for the students' history learning outcomes in the Expository learning the probability value $=0.763>=0.05$. The hypothesis $(\mathrm{H} 1)$ is accepted, which means that the data taken tend to be the same or homogeneous.

In connection with the results of the Independent Sample T-test as an inferential test, determine the difference between students' history learning activities and outcomes between those applying the inquiry learning model and those applying expository learning. The sig-probability value $=0.007<=0.05$ and the score obtained t count $=2.821>\mathrm{t}$ table $=2.004$ and $\mathrm{df}$ (degrees of freedom $)=54$, which ensures that there is a difference in the average score between the history learning outcomes of students who are taught the Inquiry learning model and the Expository learning model.

\section{DISCUSSION}

The analysis results indicate that learning using the inquiry learning model can affect the activities of students to improve student learning outcomes. In practice, students are active in class, especially in asking and responding to questions from the teacher so that there is a pleasant closeness between students and teachers. In contrast to the implementation of expository learning, the process of delivering material orally from a teacher to a group of students to master the subject matter optimally. In the learning model, the subject matter is delivered directly by the educator/teacher. Students do not find to find the material. Because the expository learning model is more on the process of speaking by educators/teachers in delivering material, the active process of students in the learning process is less attention and is not conducive.

\section{Differences between Students' History Learning Activities in Inquiry Learning and Expository Learning Model}

We are assessing student learning activities using an observation questionnaire that has a rating scale. The rating scale is used as the basis for determining the percentage of students' learning gains, both in classes using the Inquiry learning model or those applying Expository learning. The following describes the percentage of learning activities taught using the Inquiry learning model and those taught with Expository learning.

From the data from the analysis of the distribution of the percentage of historical learning activity data, it was found that the average activity level of the experimental group students was $79.16 \%$ in the high category. In comparison, the control group only reached $15.62 \%$ in the high category. When viewed from the overall average of learning activities, the experimental group and control group were obtained. These findings show that the activeness of students in the experimental group is better than the control group. So it can be said that the inquiry learning model is more effective for creating practical activities during learning than expository learning. It 
is in Arikunto's opinion which states that learning activities are said to be good if the percentage of implementation of learning activities is more than 76\% (Arikunto, 2010; Arikunto, 2019).

The achievement of the condition of student activity between the experimental group and the control group occurred during the discussion. Conditioning students will achieve a practical learning situation to carry out activities independently to obtain information. This condition is believed that the situation will determine what activities will be carried out for learning purposes (Rahmadhani, Rahmat \& Purwianingsinh, 2016). It is a self-study with the opinion of Hamalik, which states that effective teaching is teaching that provides opportunities or does one's activities (Hamalik, 2009). In addition, to increase students' activeness during the learning process, educators/teachers can give rewards in the form of values to actively involved students during learning. With the award, students prefer to express opinions, ask or answer questions.

From the results of the percentage of student activity, it can be seen that the inquiry learning model is higher than the expository learning model. What supports these differences is the learning model in each student's learning to find material related to the subject. In addition, from the results of the inferential test calculations obtained sig-probability $=0.000<=0.05$ and the acquisition value of $\mathrm{t}$ arithmetic $=6.297>\mathrm{t}$ table $=2.004$, which can be said that there is a difference in the average percentage score between the history learning activities of students who taught with the Inquiry learning model and the Expository learning model. Observations also support this during the research implementation process. The activities of participants who are taught with the inquiry learning model make students carry out learning activities. Students are more active and do not hesitate to ask questions about the subject matter. They try to find solutions to the problems given. Unlike the case with student learning activities in expository learning, the involvement and activities of students in the learning process are less active because educators/teachers are still the center of learning and only explain definitions and theories in the process of implementing learning. It causes some students not to be too enthusiastic about following the lesson. Even some students are seen following the learning process.

\section{Differences between Students' History Learning Outcomes in Inquiry Learning and Expository Learning Model}

In the student assessment process, two stages are carried out, namely the pretest stage and the posttest stage, but what will be used as a reference as the final learning outcome for participants in the posttest result, because the pretest is intended as a primary example of research. The following describes the learning outcomes of students who are taught using the Inquiry and Expository learning models.

The results of the learning history of students who were taught using the inquiry learning model obtained an average score of 76.04, while for the control group taught by expository learning, an average score of 68.75 was obtained. From the data results from the two classes that received different treatment, it was known that the students' history learning outcomes in the experimental group were better than the control group. This shows that there is a difference between the class taught by the inquiry learning model and the control group taught by applying expository learning. In addition to these results with statistical data inferential test, from the calculation results obtained sig-probability value $=0.007<=0.05$ and the acquisition of $\mathrm{t}$ arithmetic $=2.821>\mathrm{t}$ table $=2.004$ and $\mathrm{df}($ degrees of freedom $)=54$, then it can be said that $\mathrm{H} 0$ is rejected and $\mathrm{H} 1$ is accepted. Thus it can be said that there is a difference in the average score 
between students' history learning outcomes between those taught by applying the Inquiry learning model and the Expository learning model.

The average value produced in the experimental group of 76.04 and the control group of 68.75 shows that the inquiry learning model applied in the experimental group learning is more effective than the learning carried out in the control group using expository learning. It follows the opinion (Sukirman, 2012; Mulyasa, 2007)regarding effective learning, which states that learning is said to be effective if students have mastered the material by $65 \%$ of all material obtained or scored 65 out of a maximum value of 100 . In addition, the standards taught by schools can be used to measure the level of effectiveness of history learning outcomes, namely by minimum completeness criteria (KKM) is 75 .

\section{CONCLUSION}

There are differences in the activities and learning outcomes of students' history taught using the inquiry and expository learning models. In this case, the activities and learning outcomes of history students taught with the expository learning model are better than those taught using the expository learning model. Based on this, the researchers suggest that educators should be able to learn innovatively in choosing learning models that follow the needs of students and subject matter so that learning needs are more exciting and succeed in achieving goals. In addition, it is hoped that teachers can develop the learning process using the inquiry learning model. The limitation in this research is the number of research samples that are still relatively small. Although, it is considered adequate in the process of conducting research.

\section{REFERENCES}

Abdi, G. P. (2020). Peranan Pembelajaran Sejarah Untuk Pembentukan Karakter Siswa SD. Jurnal Pendidikan Tambusai, 4(1), 802-815.

Agung, L. (2012). Sejarah Asia Timur 1. Yogyakarta: Ombak.

Aman. (2011). Model Evaluasi Pembelajaran Sejarah. Yogyakarta: Ombak.

Anam, R. A. S. (2015). Efektivitas dan Pengaruh Model Pembelajaran Inkuiri pada Pembelajaran IPA di Sekolah Dasar. Mimbar Sekolah Dasar, 2(1), 80-89. https://doi.org/10.17509/mimbarsd.v2i1.1334

Arikunto. S. (2010). Prosedur Penelitian: Suatu Pendekatan Praktik (Edisi Revisi). Jakarta: Rineka Cipta.

Arikunto. S. (2019). Metodelogi Penelitian: Suatu Pengantar Pendidikan. Jakarta: Rineka Cipta.

Hamalik, O. (2009). Media Pendidikan Cetakan ke IV. Bandung: Citra Aditya Bakti.

Handy, M. R. N. (2021). Pembelajaran Sejarah dalam Membangun Historical Awarness dan Sikap Nasionalisme pada Peserta Didik. Prabayaksa: Journal of History Education, 1(1), 49-54.

Kuswana, W. S. (2014). Taksonomi kognitif. Bandung: Remaja Rosdakarya.

Lestariningsih, W. A., Jayusman, J., \& Purnomo, A. (2018). Penanaman Nilai-Nilai Multikultural dalam Pembelajaran Sejarah di SMA Negeri 1 Rembang Tahun Pelajaran 
2017/2018. Indonesian Journal of History Education, 6(2), 123-131.

Ma'mur, T. (2008). Upaya Meningkatkan Kualitas Pembelajaran Sejarah Melalui Historical Thinking. Bandung: Jurusan Pendidikan Sejarah FPIP.

Mulyasa, E. (2007). Kurikulum tingkat satuan pendidikan: Sebuah panduan praktis. Bandung: Remaja Rosdakarya.

Putro, H. P. N. (2012). Model Pembelajaran Sejarah untuk Meningkatkan Kesadaran Sejarah Melalui pendekatan Inkuiri. Paramita: Historical Studies Journal, 22(2).

Rahmadhani, Y., Rahmat, A., \& Purwianingsih, W. (2016). Pedagogical Content Knowledge (PCK) Guru dalam Pembelajaran Biologi SMA di Kota Cimahi. In Prosiding Seminar Nasional Sains dan Pendidikan Sains (Vol. 6, pp. 17-24).

Saiman, M. (2011). Inovasi Metode Pembelajaran Sejarah. LENTERA Jurnal Ilmu-Ilmu Sejarah, Budaya, dan Sosial), 2(04), 73-85.

Sayono, J. (2015). Pembelajaran Sejarah di Sekolah: Dari Pragmatis ke Idealis. Jurnal Sejarah dan Budaya, 7(1), 9-17.

Sirnayatin, T. A. (2017). Membangun Karakter Bangsa Melalui Pembelajaran Sejarah. SAP (Susunan Artikel Pendidikan), 1(3), 312-321.

Sugiyono. (2016). Metode Penelitian dan Pengembangan (Research and Development/R\&D). Bandung: Alfabeta.

Sukirman, D. (2012). Kurikulum Pembelajaran. Bandung: Universitas Pendidikan Indonesia.

Suryani, N. (2013). Pengembangan Model Internalisasi Nilai Karakter dalam Pembelajaran Sejarah Melalui Model Value Clarification Technique. Paramita: Historical Studies Journal, 23(2), 208219.

Susanto, A. (2014). Pengembangan Pembelajaran IPS di Sekolah Dasar. Jakarta: Prenadamedia Group. 